\title{
Article \\ Red Blood Cells-Derived Iron Self-Doped 3D Porous Carbon Networks for Efficient Oxygen Reduction
}

\author{
Zicong Zhang ${ }^{1}$, Xiangli Ru ${ }^{2, *}$, Xiaoli Yang ${ }^{1}$, Zhengyu Bai ${ }^{1, *}$ and Lin Yang ${ }^{1, *}$ \\ 1 Collaborative Innovation Center of Henan Province for Green Manufacturing of Fine Chemicals, \\ Key Laboratory of Green Chemical Media and Reactions, Ministry of Education, School of Chemistry and \\ Chemical Engineering, Henan Normal University, Xinxiang 453007, China; zzc2506522569@163.com (Z.Z.); \\ y_xl1997@126.com (X.Y.) \\ 2 Henan Key Laboratory for Environmental Pollution Control, Key Laboratory of Yellow River and Huai River \\ Water Environment and Pollution Control, Ministry of Education, School of Environment, \\ Henan Normal University, Xinxiang 453007, China \\ * Correspondence: ruxiangli@htu.edu.cn (X.R.); baizhengyu@htu.edu.cn (Z.B.); yanglin@htu.edu.cn (L.Y.)
}

check for updates

Citation: Zhang, Z.; Ru, X.; Yang, X.; Bai, Z.; Yang, L. Red Blood Cells-Derived Iron Self-Doped 3D Porous Carbon Networks for Efficient Oxygen Reduction. Catalysts 2022, 12, 273. https://doi.org/10.3390/ catal12030273

Academic Editor: Keith Hohn

Received: 31 December 2021

Accepted: 18 February 2022

Published: 28 February 2022

Publisher's Note: MDPI stays neutral with regard to jurisdictional claims in published maps and institutional affiliations.

Copyright: (C) 2022 by the authors. Licensee MDPI, Basel, Switzerland. This article is an open access article distributed under the terms and conditions of the Creative Commons Attribution (CC BY) license (https:// creativecommons.org/licenses/by/ $4.0 /)$.

\begin{abstract}
In addition to $\mathrm{C}, \mathrm{H}$ and $\mathrm{O}$, some biomass is also rich in mineral elements. The recovery and utilization of special mineral elements is of great significance to prepare functional materials and alleviate the current energy shortage. Herein, we describe a facile strategy for making full use of the chemical composition ( $\mathrm{C}, \mathrm{Fe}$ ) and special structure of red blood cells (RBCs) from waste pig blood to fabricate a dual metal (Fe, $\mathrm{Co}$ )-nitrogen $(\mathrm{N})$-doped porous carbon catalyst by pyrolysis of a mixture of RBCs biomass, cobaltous acetate, and melamine. The porous catalyst displays a comparable activity for oxygen reduction reaction (ORR) to that of commercial $\mathrm{Pt} / \mathrm{C}$ catalyst, with a half-wave potential of $0.821 \mathrm{~V}_{\mathrm{vsRHE}}$ in alkaline media and $0.672 \mathrm{~V}_{\mathrm{vsRHE}}$ in acid electrolyte. Especially, the as-prepared catalyst shows excellent methanol tolerance and stability in both acidic and alkaline electrolytes, which is superior to commercial Pt/C catalysts. The excellent ORR activity of FeCo-N/C $\mathrm{C}_{(\mathrm{RBC})}$ can be ascribed to the porous morphology and the cooperation between metal and nitrogen species. This work provides a novel idea of exploiting the composition of renewable biomass to modulate the activity and stability of carbon-based ORR catalysts.
\end{abstract}

Keywords: oxygen reduction reaction; biomass; non-precious catalyst; self-doped

\section{Introduction}

With the depletion of traditional energy and the environmental crisis, the demand for renewable and green energy is becoming more and more urgent [1-4]. Eco-friendly energy storage and energy conversion devices, such as rechargeable metal-air batteries and fuel cells with high energy-density and potential, have shown great potential in renewable energy technology [5-8]. As the cathode catalytic reaction of metal-air batteries and fuel cells, ORR is an important process since it determines the efficiency of the relevant electrochemical energy conversion devices [9]. Until now, the most effective electrocatalysts are Pt-based materials [10,11]. However, the Pt-based catalysts scarcity and high cost, as well as its susceptibility to $\mathrm{CH}_{3} \mathrm{OH}$ poisoning have severely limited their general application of related technologies [12,13]. Therefore, exploring novel and effective non-precious ORR electrocatalysts as substitutes for noble metal is of great value $[14,15]$.

Carbon-based catalysts are the most promising ORR non-precious electrode materials because of their superior thermal, mechanical and electronic properties. In this regard, various kinds of carbon materials, such as graphene, activated carbon, biochar, have been extensively explored [16,17]. However, pristine carbon materials with limited ORR activity are inert and have the following disadvantages: (i) low degree of dopant atoms, such as pyridinic N, resulting in a lack of catalytically active sites; (ii) underdeveloped porous structure, leading to low effective specific surface area, which affects the exposure of active 
sites and the transport of substances; (iii) poor stability. Heteroatom doped carbon-based materials with low cost, easy handleability, earth abundance and long-term stability have been proposed to be an effective way to address these issues [18-21]. Among the studied doped carbon materials, codoped metal-nitrogen carbon materials have aroused great interest because of their unique electronic structures and promising ORR activities both in alkaline and acidic media [22-24]. However, conventional carbon sources for the preparation of carbon materials mainly focus on non-renewable materials, such as petroleum and coal products, which do not meet the requirements of sustainable development [25-27]. Therefore, considering the economic benefits and sustainability, biomass should be the best promising carbon source for the synthesis of carbon-based materials.

Biomass is a sustainable and renewable carbon-rich material, which has been widely used as a green carbon source to synthesize various carbon-based products. For example, Wang et al. used grains as precursors to prepare a hollow three-dimensional (3D) porous carbon framework [28]. Sevilla et al. fabricated graphitic carbon nanostructures (GCNs) from pinewood sawdust and investigated the application of GCNs as a support to prepare Pt electrocatalysts [29]. In fact, some biomass not only contains abundant C, but also N, S, $\mathrm{P}$, etc., and $\mathrm{Fe}, \mathrm{Cu}, \mathrm{Mn}, \mathrm{Mo}, \mathrm{Zn}$. Therefore, in addition to exploiting the carbon element in biomass, the mineral elements in biomass can also be used to synthesize heteroatom-doped carbon materials to reduce energy waste [30-34]. Thus, more attention should be focused on the utilization of special mineral elements.

Red blood cells (RBCs), are double-concave disc-shaped, contain abundant C, N, Fe and other elements, and could biologically catalyze ORR with Fe-N centers in hemoglobin. Such unique characteristics could be utilized in the preparation of heteroatom doped carbon materials [35-37]. Furthermore, RBCs from animals are easily obtained from slaughterhouses. Herein, we describe a facile strategy, in which we can utilize the chemical composition and special structure of red blood cells from waste pig blood to prepare a dual metal (Fe, Co)-nitrogen-doped porous carbon catalyst by pyrolysis of a mixture of RBCs, cobalt acetate, and melamine. The porous $\mathrm{FeCo}-\mathrm{N} / \mathrm{C}_{(\mathrm{RBC})}$ catalyst with remarkable stability and high tolerance to methanol poisoning exhibits excellent ORR catalytic ability in both acidic and alkaline medium, which is highly comparable to commercial $\mathrm{Pt} / \mathrm{C}$ catalyst.

\section{Results and Discussion}

The fabrication process of the RBC-derived iron self-doped 3D porous carbon catalyst $\left(\mathrm{FeCo}-\mathrm{N} / \mathrm{C}_{(\mathrm{RBC})}\right)$ is shown in Figure 1 . The synthesis process involves the impregnation of discarded RBCs with $\operatorname{Co}(\mathrm{Ac})_{2}$, melamine and pyrolysis under high temperature in an $\mathrm{N}_{2}$ atmosphere. The FeCo-N/C (RBC) displays a double concave-disk shape with a porous structure.

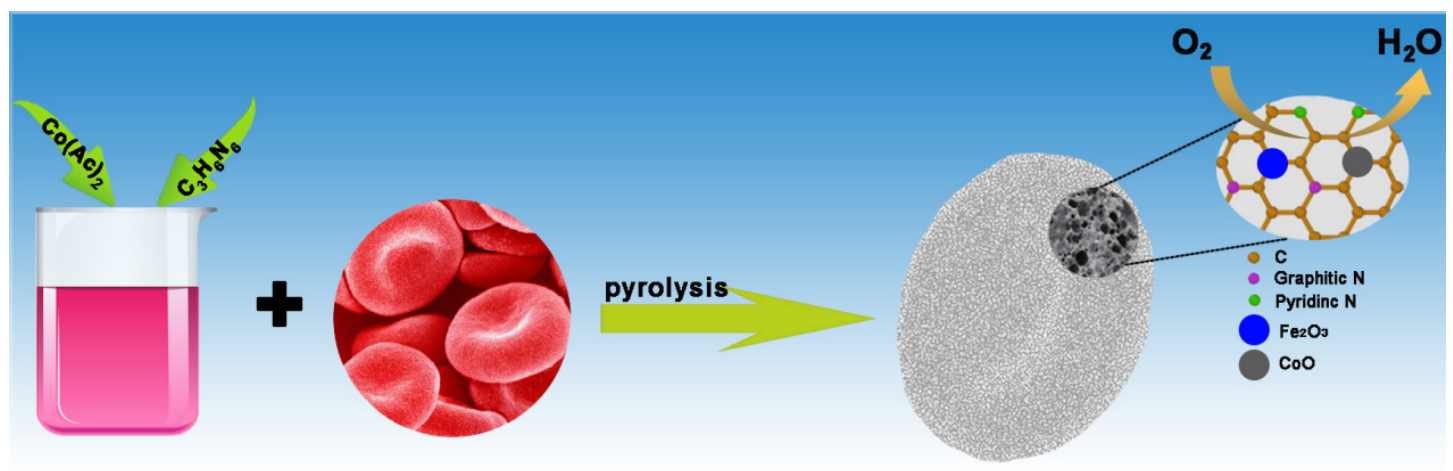

Figure 1. The formation process of $\mathrm{FeCo}-\mathrm{N} / \mathrm{C}_{(\mathrm{RBC})}$.

The morphology and structure of the catalysts were analyzed by FESEM and TEM. The FeCo-N/C $(\mathrm{RBC})$ displays a porous $\mathrm{RBC}$-shaped structure with a lateral size of about $2 \mu \mathrm{m}$ (Figure 2a). The SEM image at higher magnification demonstrates that the FeCo- 
$\mathrm{N} / \mathrm{C}_{(\mathrm{RBC})}$ possesses large amounts of pores (Figure $2 \mathrm{~b}$ ). The porous structure increases the specific surface area of the catalyst, which is conducive to exposing more internal active sites and increasing the contact area with the substrates. Furthermore, we also find cobalt acetate and melamine play a critical role in the formation of the porous RBCshaped structure. Pure RBCs after calcination (namely, $\mathrm{Fe}-\mathrm{C}_{(\mathrm{RBC})}$ ) have no porous structure and only a small fraction maintain the original morphology of the double concave-disk shape (Figure S1a). With the addition of melamine, the amount of the double concavedisk shape increases (Figure S1b). Therefore, the doping of melamine strengthens the thermal stability of the precursor to a certain extent [22,38,39], and the double concave disk shape cannot be sintered and broken after high-temperature calcination. Moreover, with the addition of cobalt acetate, the catalyst exhibits a porous structure, but cannot maintain the original morphology of RBC (Figure S1c). That may be because cobalt acetate not only provides the cobalt source doping catalyst [40] but also assumes the role of internal pore generation. Then, the samples were further analyzed by transmission electron microscope image (TEM). A TEM image (Figure 2) reveals a hole-like structure inside FeCo$\mathrm{N} / \mathrm{C}_{(\mathrm{RBC})}$, further demonstrating the porous structure of the catalyst. Figure $2 \mathrm{~d}$ is the highresolution transmission electron microscope (HRTEM) image of the $\mathrm{FeCo}-\mathrm{N} / \mathrm{C}_{(\mathrm{RBC})}$, which indicates that there are two different spacing lattice fringes, $2.953 \mathrm{~nm}$ and $2.460 \mathrm{~nm}$, which corresponds to the (220) diffraction surface of $\mathrm{Fe}_{2} \mathrm{O}_{3}$ and (111) diffraction surface of $\mathrm{CoO}$, respectively. Moreover, the HRTEM image and the corresponding element mappings show the uniform distribution of $\mathrm{C}, \mathrm{N}, \mathrm{O}, \mathrm{Fe}$ and $\mathrm{Co}$ in FeCo-N/C $\mathrm{C}_{(\mathrm{RBC})}$ (Figure 2e), indicating the co-existence of $\mathrm{N}, \mathrm{O}, \mathrm{Fe}$ and $\mathrm{Co}$ species within the carbon network. Moreover, the $\mathrm{Fe}, \mathrm{N}$ and $\mathrm{C}$ species may be derived from proteins in RBCs. Besides, the content of $\mathrm{Fe}$ and Co elements in $\mathrm{Fe}-\mathrm{C}_{(\mathrm{RBC})}, \mathrm{Fe}-\mathrm{N} / \mathrm{C}_{(\mathrm{RBC})}, \mathrm{FeCo}-\mathrm{C}_{(\mathrm{RBC})}$ and $\mathrm{FeCo}-\mathrm{N} / \mathrm{C}_{(\mathrm{RBC})}$, determined by inductively coupled plasma mass spectrometry (ICP-MS), are $2.6 \mathrm{wt} \%$ and $0.0 \mathrm{wt} \%$ (equaling to 0.59 atomic\% and 0.00 atomic\%), $2.5 \mathrm{wt} \%$ and $0.0 \mathrm{wt} \%$ (0.57 atomic $\%$ and 0.00 atomic\%), $2.4 \mathrm{wt} \%$ and $4.3 \mathrm{wt} \%$ (0.56 atomic\% and 0.97 atomic\%), $2.3 \mathrm{wt} \%$ and $4.3 \mathrm{wt} \%$ (0.54 atomic\% and 0.96 atomic\%), respectively. The ICP-MS results further verify that $\mathrm{Fe}$ and Co species are derived from proteins in RBCs and pore-forming agent cobalt acetate, respectively. Therefore, the porous double concave disk shaped $\mathrm{FeCo}-\mathrm{N} / \mathrm{C}_{(\mathrm{RBC})}$ is successfully fabricated.

The phase composition of $\mathrm{Fe}-\mathrm{C}_{(\mathrm{RBC})}, \mathrm{Fe}-\mathrm{N} / \mathrm{C}_{(\mathrm{RBC})}, \mathrm{FeCo} \mathrm{C}_{(\mathrm{RBC})}$ and $\mathrm{FeCo}-\mathrm{N} / \mathrm{C}_{(\mathrm{RBC})}$ was characterized by XRD (Figure $3 \mathrm{a}$ ). All samples show two obvious broad diffraction peaks at $23^{\circ}$ and $44^{\circ}$, which can be assigned to the stacking of (002) carbon layers and (101) ordered hexagonal carbon layers, respectively. Moreover, the (002) diffraction peak of Fe-N/ $\mathrm{C}_{(\mathrm{RBC})}, \mathrm{FeCo}-\mathrm{C}_{(\mathrm{RBC})}$ and the $\mathrm{FeCo}-\mathrm{N} / \mathrm{C}_{(\mathrm{RBC})}$ are significantly shifted to a lower angle compared with that of $\mathrm{Fe}-\mathrm{C}_{(\mathrm{RBC})}$, indicating that doping can lead to the expansion of the carbon layer spacing and distortion of carbon material structure. However, the (002) and (101) peak intensities of FeCo-N/ $\mathrm{C}_{(\mathrm{RBC})}$ are much lower than those of $\mathrm{Fe}-\mathrm{C}_{(\mathrm{RBC})}$, $\mathrm{Fe}-\mathrm{N} / \mathrm{C}_{(\mathrm{RBC})}$ and $\mathrm{FeCo}-\mathrm{C}_{(\mathrm{RBC})}$, revealing that $\mathrm{FeCo}-\mathrm{N} / \mathrm{C}_{(\mathrm{RBC})}$ has a lower degree of graphitization than $\mathrm{Fe}-\mathrm{C}_{(\mathrm{RBC})}, \mathrm{Fe}-\mathrm{N} / \mathrm{C}_{(\mathrm{RBC})}$ and $\mathrm{FeCo}-\mathrm{C}_{(\mathrm{RBC})}$. This indicates that the addition of $\mathrm{Co}$ and $\mathrm{N}$ affects the pyrolysis or reduces the graphitization of the catalyst. In addition, the peaks appearing at $36.5^{\circ}, 42.4^{\circ}$ and $61.5^{\circ} \mathrm{can}$ be ascribed to the (111), (200) and (220) lattice planes of $\mathrm{CoO}$ (JCPDS No.48-1719), Other peaks at $30.2^{\circ}, 35.6^{\circ}, 43.2^{\circ}, 57.2^{\circ}$ and $62.9^{\circ}$ can be ascribed to the (220), (311), (400), (511) and (440) planes of $\mathrm{Fe}_{2} \mathrm{O}_{3}$ (JCPDS No.39-1346). This reveals that most $\mathrm{Co}$ or Fe species exist in $\mathrm{FeCo}-\mathrm{N} / \mathrm{C}_{(\mathrm{RBC})}$ catalyst as $\mathrm{CoO}$ or $\mathrm{Fe}_{2} \mathrm{O}_{3}$. The Raman spectra (Figure $3 b$ ) of all four samples show two obvious peaks at $\sim 1350 \mathrm{~cm}^{-1}$ (D band) and $\sim 1580 \mathrm{~cm}^{-1}$ (G band). The $\mathrm{D}$ band can reflect the defect and disorder of carbon material caused by vacancy and heteroatomic doping. The $G$ band is assigned to the vibrational phonon $\mathrm{E}_{2 \mathrm{~g}}$ of the $\mathrm{sp}^{2}$-hybridized bond in the carbon atom, revealing the degree of graphitization of carbon material, including $\mathrm{C}-\mathrm{C}$ and $\mathrm{C}-\mathrm{N}$ bonds, respectively. The $I_{\mathrm{D}} / I_{\mathrm{G}}$ peak intensity ratios (area) of $\mathrm{FeCo}-\mathrm{N} / \mathrm{C}_{(\mathrm{RBC})}, \mathrm{Fe}-\mathrm{C}_{(\mathrm{RBC})}, \mathrm{Fe}-\mathrm{N} / \mathrm{C}_{(\mathrm{RBC})}$ and $\mathrm{FeCo}-\mathrm{C}_{(\mathrm{RBC})}$ are 1.27, 1.09, 1.17 and 1.06, respectively. The results demonstrate that the introduction of $\mathrm{Co}$ and $\mathrm{N}$ increases the concentration of catalyst defect sites, but reduces the degree of 
graphitization, which may be caused by the distortion of carbon lattice induced by doping. The above results demonstrate that the doping of $\mathrm{Co}$ and $\mathrm{N}$ improves the defect sites concentration of biomass-derived $\mathrm{FeCo}-\mathrm{N} / \mathrm{C}_{(\mathrm{RBC})}$ catalyst, confirming the XRD results.
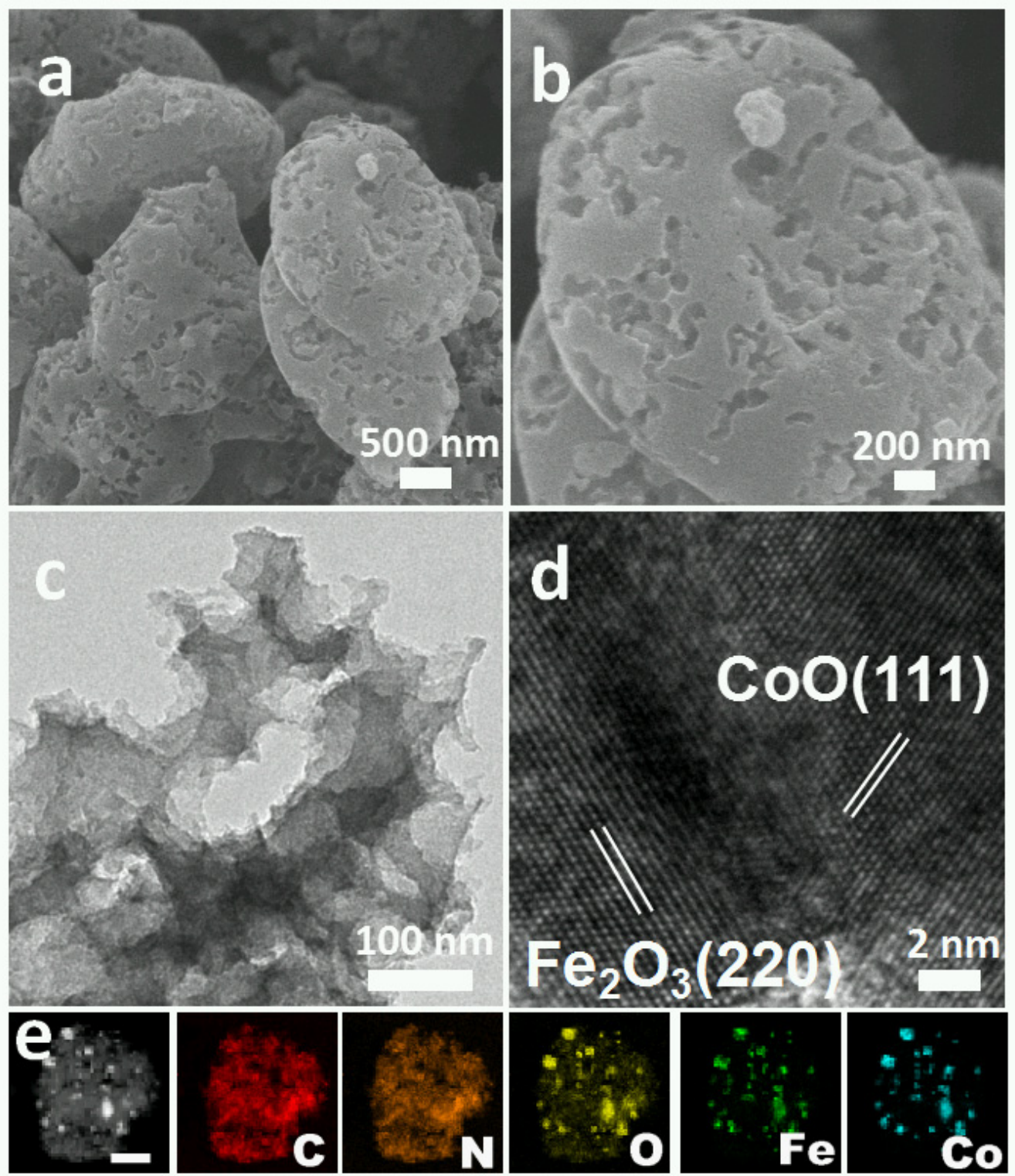

Figure 2. $(\mathbf{a}, \mathbf{b})$ FESEM images of FeCo-N/C $\mathrm{C}_{(\mathrm{RBC})}$. (c) TEM images of FeCo-N/C $\mathrm{C}_{(\mathrm{RBC})}$. $(\mathbf{d}) \mathrm{HR}-\mathrm{TEM}$ images of $\mathrm{FeCo}-\mathrm{N} / \mathrm{C}_{(\mathrm{RBC})}$. (e) TEM image of $\mathrm{FeCo}-\mathrm{N} / \mathrm{C}_{(\mathrm{RBC})}$ and the corresponding elemental mappings, the scale of length is $1 \mu \mathrm{m}$. 

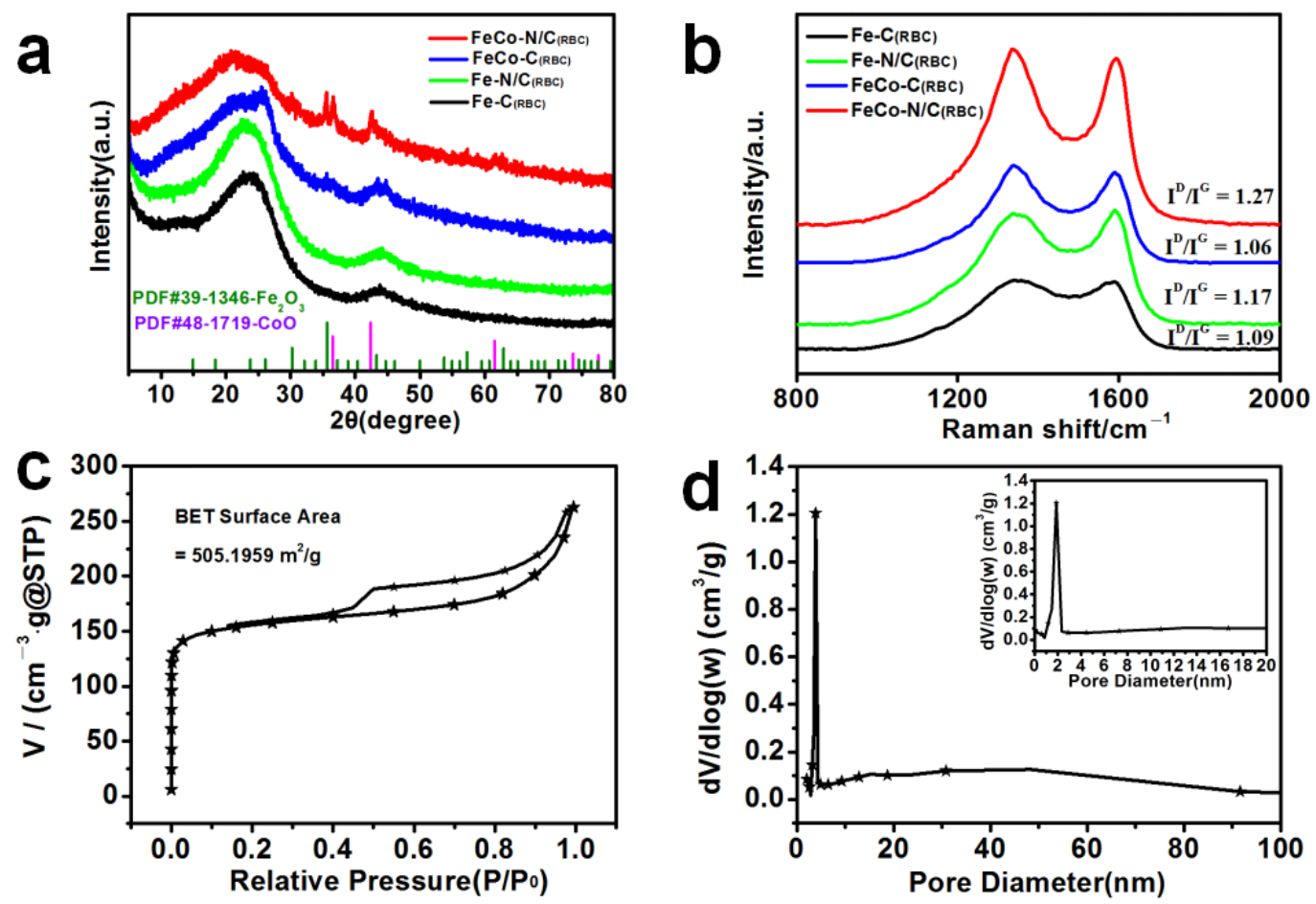

Figure 3. (a) XRD patterns of $\mathrm{Fe}-\mathrm{C}_{(\mathrm{RBC})}, \mathrm{Fe}-\mathrm{N} / \mathrm{C}_{(\mathrm{RBC})}, \mathrm{FeCo}-\mathrm{C}_{(\mathrm{RBC})}$ and $\mathrm{FeCo}-\mathrm{N} / \mathrm{C}_{(\mathrm{RBC})}$. (b) Raman spectra of $\mathrm{Fe}-\mathrm{C}_{(\mathrm{RBC})}, \mathrm{Fe}-\mathrm{N} / \mathrm{C}_{(\mathrm{RBC})}, \mathrm{FeCo}-\mathrm{C}_{(\mathrm{RBC})}$ and $\mathrm{FeCo}-\mathrm{N} / \mathrm{C}_{(\mathrm{RBC})} \cdot(\mathrm{c}) \mathrm{N}_{2}$ adsorption-desorption isotherms of FeCo-N/C $(R B C)$. (d) Pore-size distributions of $\mathrm{FeCo}-\mathrm{N} / \mathrm{C}_{(\mathrm{RBC})}$, top right corner is the enlarged view of the graph.

The specific surface area and porosity of the four samples were measured by nitrogen adsorption/desorption techniques. The specific surface area of FeCo-N/ $\mathrm{C}_{(\mathrm{RBC})}, \mathrm{Fe}-\mathrm{C}_{(\mathrm{RBC})}$, $\mathrm{Fe}-\mathrm{N} / \mathrm{C}_{(\mathrm{RBC})}$ and $\mathrm{FeCo}-\mathrm{C}_{(\mathrm{RBC})}$ are $505.2 \mathrm{~m}^{2} / \mathrm{g}, 85.1 \mathrm{~m}^{2} / \mathrm{g}, 292.4 \mathrm{~m}^{2} / \mathrm{g}$ and $381.4 \mathrm{~m}^{2} / \mathrm{g}$ (Figures $3 \mathrm{c}$ and S2), respectively. Obviously, the doping of $\mathrm{Co}$ and $\mathrm{N}$ in the precursor significantly improves the specific surface area of the samples and forms a 3D porous network. Moreover, the pore size distributions of the four catalysts were also assessed using the Brunauer-Emmett-Teller (BET) method. The pore-size distribution curves demonstrate that $\mathrm{Fe}-\mathrm{C}_{(\mathrm{RBC})}, \mathrm{Fe}-\mathrm{N} / \mathrm{C}_{(\mathrm{RBC})}, \mathrm{FeCo}-\mathrm{C}_{(\mathrm{RBC})}$ and $\mathrm{FeCo}-\mathrm{N} / \mathrm{C}_{(\mathrm{RBC})}$ all possess a typical mesoporous structure (Figures $3 \mathrm{~d}$ and $\mathrm{S} 2$ ). The pore diameter of $\mathrm{FeCo}-\mathrm{C}_{(\mathrm{RBC})}$ and $\mathrm{FeCo}-$ $\mathrm{N} / \mathrm{C}_{(\mathrm{RBC})}$ is nearly the same, indicating the Co dopant plays an important role in the formation of the mesoporous structure. However, compared with $\mathrm{FeCo}^{-} \mathrm{C}_{(\mathrm{RBC})}$ (Figure S2), the specific surface area of FeCo-N/C $\mathrm{C}_{(\mathrm{RBC})}$ is higher, which may be due to the doping of melamine strengthening the thermal stability of the precursor, maintaining the pore structure (Figures $2 \mathrm{~b}$ and S1c). The mesoporous structure and high specific surface area can expand the electrochemically active surface area of the catalyst, and accelerate the transfer rate of reactants and products, obtaining higher electrochemical activity [41,42].

The surface chemical compositions of FeCo-N/C $\mathrm{C}_{(\mathrm{RBC})}$ were detected by X-ray photoelectron spectrometry (XPS). The full XPS spectrum of FeCo-N/C $\mathrm{C}_{(\mathrm{RBC})}$ (Figure 4a) proves the existence of Co 2p, Fe 2p, O 1s, N 1s and C 1s in the catalyst. Moreover, the atomic contents of $\mathrm{C} 1 \mathrm{~s}, \mathrm{Fe} 2 \mathrm{p}, \mathrm{N}$ 1s, $\mathrm{O}$ 1s and $\mathrm{Co} 2 \mathrm{p}$ in all samples (Table S1) indicate that the Fe and $\mathrm{C}$ species are derived from RBCs, and the $\mathrm{N}$ species is partly from RBCs. The high-resolution XPS spectra of $\mathrm{C} 1 \mathrm{~s}$ indicates that FeCo-N $/ \mathrm{C}_{(\mathrm{RBC})}$ contains sp $\mathrm{s}^{2}$-hybridized carbon, nitrogen-carbon and oxygen-containing moieties (Figure $4 \mathrm{~b}$ ). Figure $4 \mathrm{c}$ shows the Co $2 \mathrm{p}$ spectra of the $\mathrm{FeCo}-\mathrm{N} / \mathrm{C}_{(\mathrm{RBC})}$ catalyst, which can be resolved into four peaks, centered at 780.9, 796.5, 802.9 and $786.2 \mathrm{eV}$. More specifically, the peaks at 780.9 and $796.5 \mathrm{eV}$ are assigned to $C_{0} 2 p_{3 / 2}$ and $C_{o} 2 p_{1 / 2}$, respectively, which is similar to the binding energies of $\mathrm{CoO} 2 \mathrm{p}_{3 / 2}(781.1 \mathrm{eV})$ and $\mathrm{CoO} 2 \mathrm{p}_{1 / 2}(796.3 \mathrm{eV})$ [43], indicating the presence of $\mathrm{Co}^{2+}$ existing in the form of $\mathrm{CoO}$ in $\mathrm{FeCo}-\mathrm{N} / \mathrm{C}_{(\mathrm{RBC})}$ catalyst. The two peaks at 802.9 and $786.2 \mathrm{eV}$ 
correspond to Co $2 \mathrm{p}_{3 / 2}$ and Co $2 \mathrm{p}_{1 / 2}$ satellites, respectively. The Fe $2 \mathrm{p}$ spectrum (Figure $4 \mathrm{~d}$ ) can be deconvoluted into four peaks located at $725.8,712.9,732.9$ and $718.9 \mathrm{eV}$. The presence of the peaks at 725.8 and $712.9 \mathrm{eV}$ specifically correspond to the binding energies of $2 \mathrm{p}_{1 / 2}$ and $2 \mathrm{p}_{3 / 2}$ of $\mathrm{Fe}^{3+}$ in $\mathrm{FeCo}-\mathrm{N} / \mathrm{C}_{(\mathrm{RBC})}$ [44], respectively. These results agree well with the XRD result. The high-resolution N1s spectra (Figures 4e and S3) of the four samples can be deconvoluted into four peaks at 398.6, 399.9, 401.1, and $403.8 \mathrm{eV}$, corresponding to pyridinic $\mathrm{N}$, pyrrolic $\mathrm{N}$, graphitic $\mathrm{N}$, and oxide $\mathrm{N}$, respectively. Generally, pyridinic $\mathrm{N}$ is widely recognized as an efficient active site for ORR. The pyridinic $\mathrm{N}$ content of $\mathrm{Fe}-\mathrm{C}_{(\mathrm{RBC})}$, $\mathrm{Fe}-\mathrm{N} / \mathrm{C}_{(\mathrm{RBC})}, \mathrm{FeCo}-\mathrm{C}_{(\mathrm{RBC})}$ and $\mathrm{FeCo}-\mathrm{N} / \mathrm{C}_{(\mathrm{RBC})}$ are $20.78 \%, 15.17 \%, 20.97 \%, 25.21 \%$, respectively. Moreover, the high-resolution XPS O 1s spectra of the as-prepared FeCo-N/ $\mathrm{C}_{(\mathrm{RBC})}$ catalyst (Figure $4 \mathrm{f})$ are also deconvoluted into metal-O (531.1 eV), metal-OH $(532.8 \mathrm{eV})$ and $\mathrm{C}-\mathrm{O}(536.6 \mathrm{eV})$ [44]. These oxygen-containing moieties indicate that there are chemically bonded oxygen groups in FeCo-N/ $\mathrm{C}_{(\mathrm{RBC})}$, which can physically adsorb oxygen and enhance the ORR. Based on the above results, the $\mathrm{FeCo}-\mathrm{N} / \mathrm{C}_{(\mathrm{RBC})}$ should have a high catalytic activity towards ORR [33].
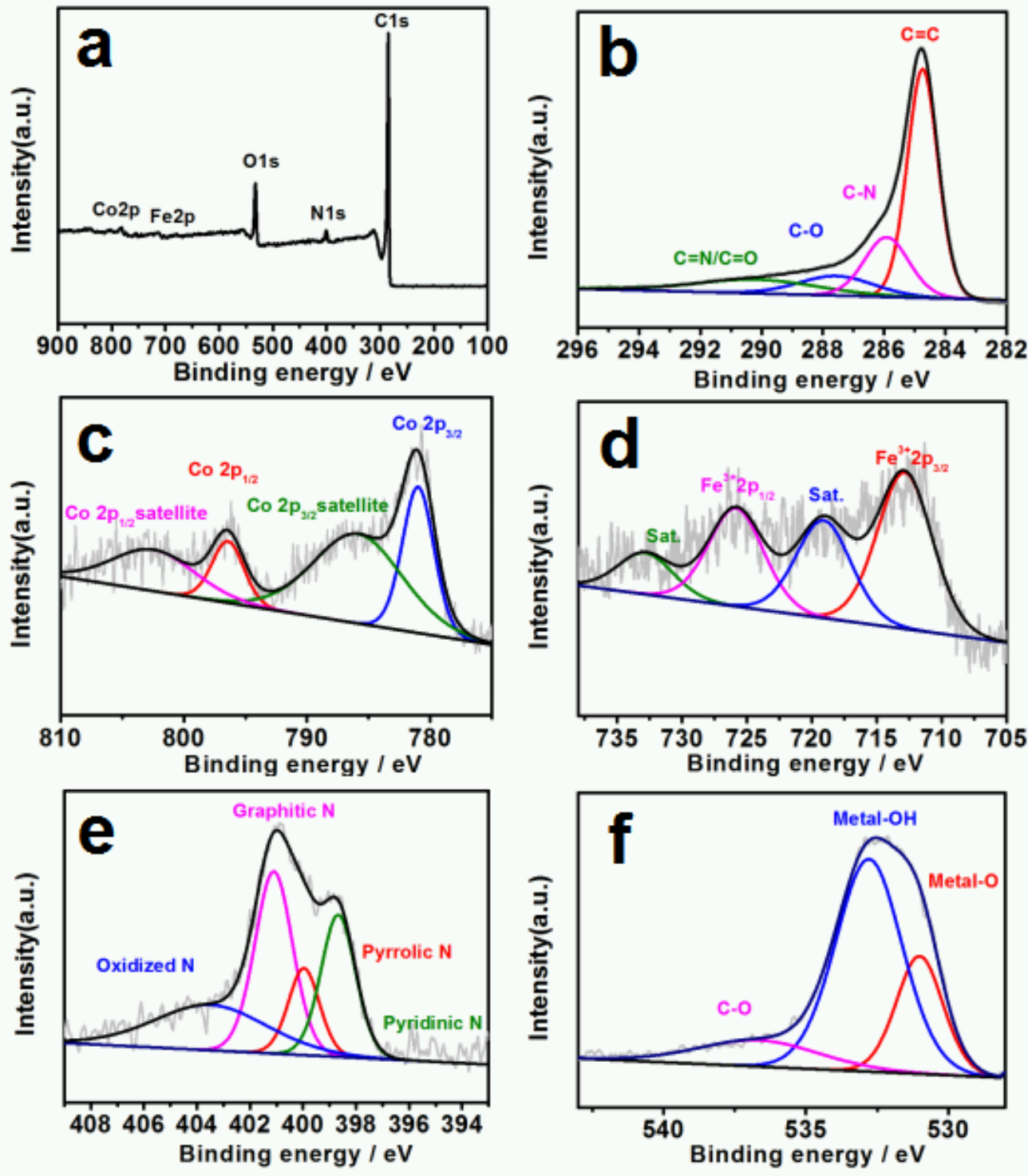

Figure 4. (a) Full XPS spectrum of FeCo-N/C $(\mathrm{RBC})$, deconvoluted. (b) C 1s, (c) Co 2p, (d) Fe 2p (e) N 1 s and (f) $\mathrm{O} 1$ s spectra of $\mathrm{FeCo}-\mathrm{N} / \mathrm{C}_{(\mathrm{RBC})}$. 
The ORR activity of the obtained catalysts was investigated in two kinds of electrolytes including $\mathrm{KOH}(0.1 \mathrm{M})$ and $\mathrm{HClO}_{4}(0.1 \mathrm{M})$ via cyclic voltammetry $(\mathrm{CV})$ and linear sweep voltammetry (LSV) on rotating disk electrode (RDE). Figure 5a shows the LSV curves of Fe$\mathrm{C}_{(\mathrm{RBC})}, \mathrm{Fe}-\mathrm{N} / \mathrm{C}_{(\mathrm{RBC})}, \mathrm{FeCo}-\mathrm{C}_{(\mathrm{RBC})}, \mathrm{FeCo}-\mathrm{N} / \mathrm{C}_{(\mathrm{RBC})}$ and commercial $\mathrm{Pt} / \mathrm{C}$ in $\mathrm{O}_{2}$-saturated $0.1 \mathrm{M} \mathrm{KOH}$ solution at 1600 rotating speed. The ORR activities of the four catalysts increased in the order of Fe- $\mathrm{C}_{(\mathrm{RBC})}<\mathrm{Fe}-\mathrm{N} / \mathrm{C}_{(\mathrm{RBC})}<\mathrm{FeCo}-\mathrm{C}_{(\mathrm{RBC})}<\mathrm{FeCo}-\mathrm{N} / \mathrm{C}_{(\mathrm{RBC})}$, and their half-wave potential are $0.68 \mathrm{~V}_{\mathrm{vsRHE}}, 0.69 \mathrm{~V}_{\mathrm{vsRHE}}, 0.74 \mathrm{~V}_{\mathrm{vsRHE}}$ and $0.83 \mathrm{~V}_{\mathrm{vsRHE}}$, respectively (Figure S4). Compared with $\mathrm{Fe}-\mathrm{C}_{(\mathrm{RBC})}$, the addition of $\mathrm{Co}$ or $\mathrm{N}$ induces a positive shift in the half-wave potential of Fe-N/ $\mathrm{C}_{(\mathrm{RBC})}$, FeCo- $\mathrm{C}_{(\mathrm{RBC})}$ and $\mathrm{FeCo}-\mathrm{N} / \mathrm{C}_{(\mathrm{RBC})}$. The onset potential, half-wave potential and limiting current density of $\mathrm{FeCo}-\mathrm{N} / \mathrm{C}_{(\mathrm{RBC})}$ is $0.958 \mathrm{~V}_{\mathrm{vsRHE}}$, $0.831 \mathrm{~V}_{\mathrm{vsRHE}}$ and $5.547 \mathrm{~mA} \mathrm{~cm}^{-2}$ (Figure S4), respectively, and the half-wave potential is only $44 \mathrm{mV}$ lower than that of $20 \mathrm{wt} \% \mathrm{Pt} / \mathrm{C}$, indicating that $\mathrm{FeCo}-\mathrm{N} / \mathrm{C}_{(\mathrm{RBC})}$ has excellent ORR activity. This high ORR catalytic activity can be attributed to its unique porous structure constructed by the acetate volatilization and increased conductivity constructed by nitrogen doping, which causes a large specific surface area, exposing more active sites. To verify our hypothesis, the electrochemically active surface areas (ECSAs) of four samples were measured. Moreover, the ECSAs can be assessed by the double-capacitance layer $\left(C_{\mathrm{dl}}\right)$. The $C_{\mathrm{dl}}$ is obtained from the linear slope by plotting $\Delta j=\left(\left|j_{\text {charge }}-j_{\text {off charge }}\right|\right)$ in a faradaic silence potential range against the scan rates (Figure S5). In Figure $5 b$, the $C_{d l}$ of $F e-C_{(R B C)}$, Fe-N $/ C_{(R B C)}, F e C o-C_{(R B C)}$ and FeCo-N $/ C_{(R B C)}$ is $3.9 \mu \mathrm{F} \mathrm{cm}^{-2}, 5.4 \mu \mathrm{F} \mathrm{cm}^{-2}, 5.6 \mu \mathrm{F} \mathrm{cm}^{-2}$, and $17.9 \mu \mathrm{F} \mathrm{cm}^{-2}$, respectively. The $C_{\mathrm{dl}}$ of $\mathrm{FeCo}-\mathrm{N} / \mathrm{C}_{(\mathrm{RBC})}$ is significantly larger than that of other catalysts, indicating FeCo-N $/ \mathrm{C}_{(\mathrm{RBC})}$ has more ECSA, which is in accordance with the results of the nitrogen adsorption/ desorption test. Therefore, the higher ORR activity of FeCo-N/C $(\mathrm{RBC})$ could be partially attributed to its more electrochemical active sites. The kinetics ORR activity of FeCo-N $/ \mathrm{C}_{(\mathrm{RBC})}$ was further evaluated at different rotating rates from 400 to 2025 (Figure S6a). The limiting current density increases with the increase of rotation speed, which is due to the decreased diffusion distance at a higher rotating speed. The corresponding K-L plots of FeCo-N/C $(\mathrm{RBC})$ at different potentials show good linearity, indicating first order reaction kinetics with respect to the dissolved oxygen concentration and similar electron transfer numbers per oxygen molecule in the ORR process (Figure $5 c$ ). Besides, the electron transfer number of FeCo-N/C $(\mathrm{RBC})$ calculated from the K-L equation is 4.38, indicating a four-electron transfer pathway for the ORR process. Moreover, the Tafel slope is performed to evaluate the kinetic process. The Tafel slope of FeCo-N/C $(\mathrm{RBC})$ at a low overpotential is $91.14 \mathrm{mV} \mathrm{dec}^{-1}$, which is much lower than that of other catalysts, confirming its superior ORR activities. The low Tafel slope of FeCo-N/C $(R B C)$ is owing to the abundant active sites and the synergic effect between metal and nitrogen species, which further highlight the structural advantages of FeCo-N/C $(\mathrm{RBC})$.

Stability is another important parameter to evaluate a catalyst. The current density of the $\mathrm{FeCo}-\mathrm{N} / \mathrm{C}_{(\mathrm{RBC})}$ catalyst retains $95.3 \%$ of the initial value after $12 \mathrm{~h}$ long-term continuous ORR test in the alkaline electrolyte under $0.78 \mathrm{~V}$ potential (Figure 5e). In contrast, $20 \mathrm{wt} \%$ commercial $\mathrm{Pt} / \mathrm{C}$ under the same conditions retains only $73 \%$ activity. In addition to superior ORR activity and stability, methanol tolerance is another important aspect for potential application in fuel cells. When $3 \mathrm{M}$ methanol is added to the electrolyte, only a slight current change could be observed on the FeCo-N $/ \mathrm{C}_{(\mathrm{RBC})}$ loaded electrode, and it returns to the previous state with time increased (Figure $5 \mathrm{f}$ ). In comparison, the current density of commercial $\mathrm{Pt} / \mathrm{C}$ goes down instantaneously, only $36.76 \%$ current density could be retained after the signal is steady. These results demonstrate that $F e C o-N / C_{(R B C)}$ is the best ORR catalyst among the four as-prepared catalysts, which is contributed to by its more accessible catalytic active sites and the cooperation between metal and nitrogen species. Furthermore, the electrocatalytic ORR performances of the $\mathrm{FeCo}-\mathrm{N} / \mathrm{C}_{(\mathrm{RBC})}$ are also competitive with previous reported biomass-derived catalysts, especially when considering the recycling of elements and the electrocatalytic property in acidic electrolytes (Table S2). 

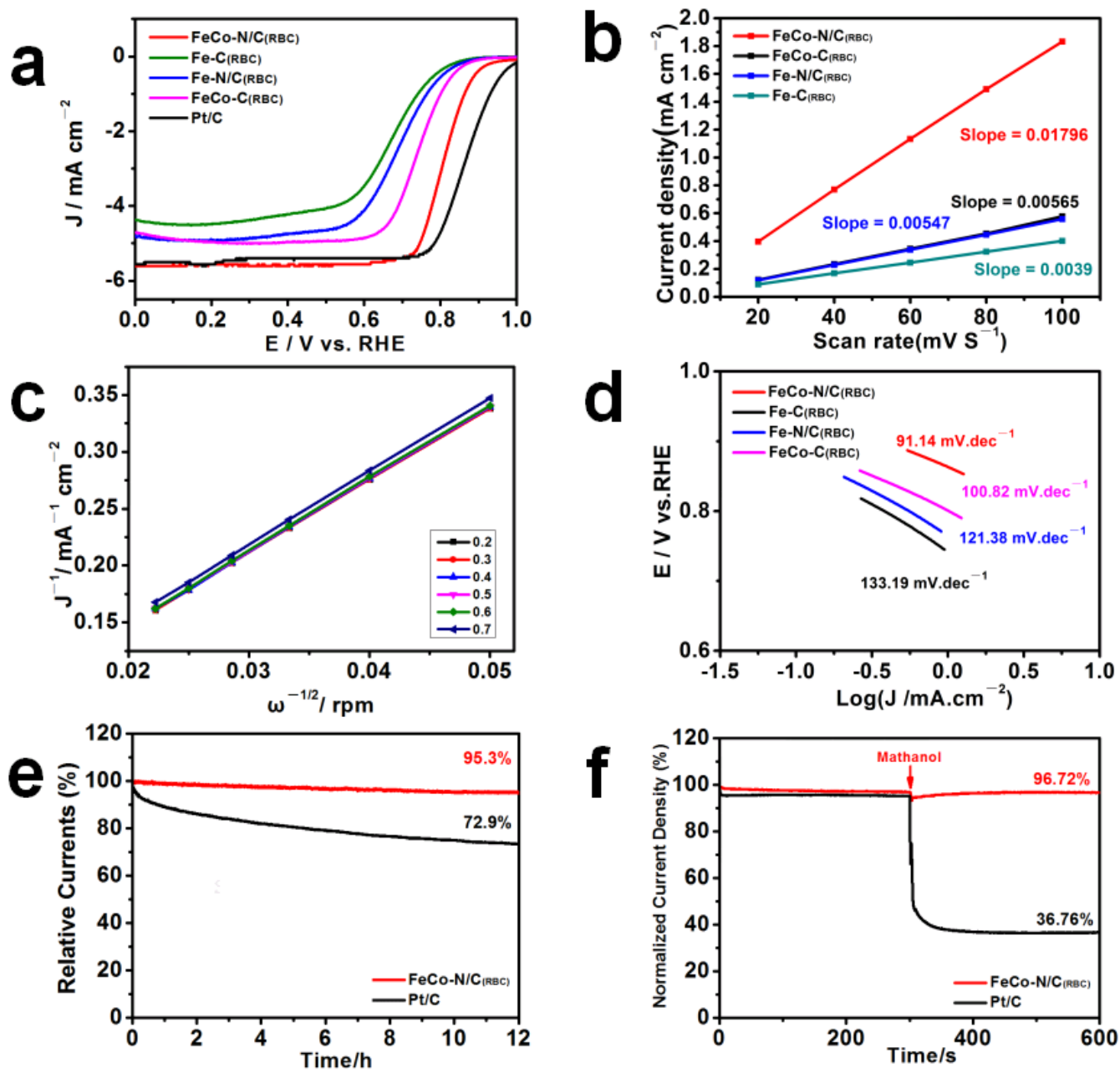

Figure 5. (a) Comparative LSVs at $1600 \mathrm{rpm}$ for four catalysts, along with $20 \mathrm{wt} \%$ commercial Pt/C in $\mathrm{O}_{2}$ saturated $0.1 \mathrm{M} \mathrm{KOH}$ solution. (b) The capacitive current as a function of the different scan rates of four catalysts for an estimate of the double-layer capacitance. (c) Kouteckye-Levich plots of FeCo-N/C $(\mathrm{RBC})$. (d) Tafel plots of four catalysts for the ORR. (e) $\mathrm{i}-\mathrm{t}$ chronoamperometric responses of $\mathrm{FeCo}-\mathrm{N} / \mathrm{C}_{(\mathrm{RBC})}$ and $20 \mathrm{wt} \%$ commercial $\mathrm{Pt} / \mathrm{C}$ at $0.78 \mathrm{~V}$ in $\mathrm{O}_{2}$-saturated $0.1 \mathrm{M} \mathrm{KOH}$. (f) $\mathrm{i}-\mathrm{t}$ chronoamperometric responses of $\mathrm{FeCo}-\mathrm{N} / \mathrm{C}_{(\mathrm{RBC})}$ and $20 \mathrm{wt} \%$ commercial $\mathrm{Pt} / \mathrm{C}$ electrodes upon the addition of $3 \mathrm{M}$ methanol.

Encouraged by the excellent performance of $\mathrm{FeCo}-\mathrm{N} / \mathrm{C}_{(\mathrm{RBC})}$ in alkaline electrolytes, we further explored the catalytic property in acid electrolytes. Figure 6a shows the LSV curves of Fe- $\mathrm{C}_{(\mathrm{RBC})}, \mathrm{Fe}-\mathrm{N} / \mathrm{C}_{(\mathrm{RBC})}, \mathrm{FeCo}-\mathrm{C}_{(\mathrm{RBC})}, \mathrm{FeCo}-\mathrm{N} / \mathrm{C}_{(\mathrm{RBC})}$ and $20 \mathrm{wt} \%$ commercial $\mathrm{Pt} / \mathrm{C}$ in $\mathrm{O}_{2}$-saturated $0.1 \mathrm{M} \mathrm{HClO}_{4}$ solution. Obviously, the FeCo-N/C $\mathrm{C}_{(\mathrm{RBC})}$ exhibits the best ORR activity among the four synthesized samples in acidic medium, and its half-wave potential and limiting current density are $0.672 \mathrm{~V}_{\mathrm{vsRHE}}$ and $5.503 \mathrm{~mA} \mathrm{~cm}^{-2}$ (Figure S7), respectively, approaching those of $\mathrm{Pt} / \mathrm{C}\left(0.798 \mathrm{~V}_{\mathrm{vsRHE}}, 6.063 \mathrm{~mA} \mathrm{~cm}{ }^{-2}\right)$. The FeCo-N/C $\mathrm{C}_{(\mathrm{RBC})}$ catalyst also shows a smaller Tafel slope at low overpotential (Figure $6 \mathrm{~b}$ ), showing good ORR kinetic performance. Although the half-wave potential and limiting current density of $\mathrm{FeCo}-\mathrm{N} / \mathrm{C}_{(\mathrm{RBC})}$ catalyst in $0.1 \mathrm{M} \mathrm{HClO}_{4}$ solution are lower than those of $20 \mathrm{wt} \%$ commercial $\mathrm{Pt} / \mathrm{C}$, it displays better stability and methanol tolerance. Alternatively, LSV performed at various rotation speeds indicates the shortened diffusion distance at higher rotating speeds (Figure S6b). As shown in Figure 6c, a continuous $12 \mathrm{~h}$ ORR test on the FeCo-N/ $\mathrm{C}_{(\mathrm{RBC})}$ coated electrode only resulted in $25.9 \%$ loss of the initial current density value, whereas that of commercial $20 \mathrm{wt} \% \mathrm{Pt} / \mathrm{C}$ decreases by $32.3 \%$. In the methanol tolerance test, the current density of $\mathrm{FeCo}-\mathrm{N} / \mathrm{C}_{(\mathrm{RBC})}$ changes slightly with the addition of $3 \mathrm{M}$ methanol, and 
it restores to $91.2 \%$ of the initial value with increased time (Figure $6 \mathrm{~d}$ ). In comparison, the current density of $20 \mathrm{wt} \%$ commercial Pt/C plummets instantaneously, only $41.4 \%$ current density could be retained after the signal is steady. Note, that FeCo-N/C $C_{(R B C)}$ demonstrates superb ORR activity and stability both in the alkaline and acid medium among the four synthesized catalysts. The excellent ORR property of FeCo-N/C $\mathrm{C}_{(\mathrm{RBC})}$ can be ascribed to the $3 \mathrm{D}$ morphological and compositional advantages, which are closely related to the rich defects.
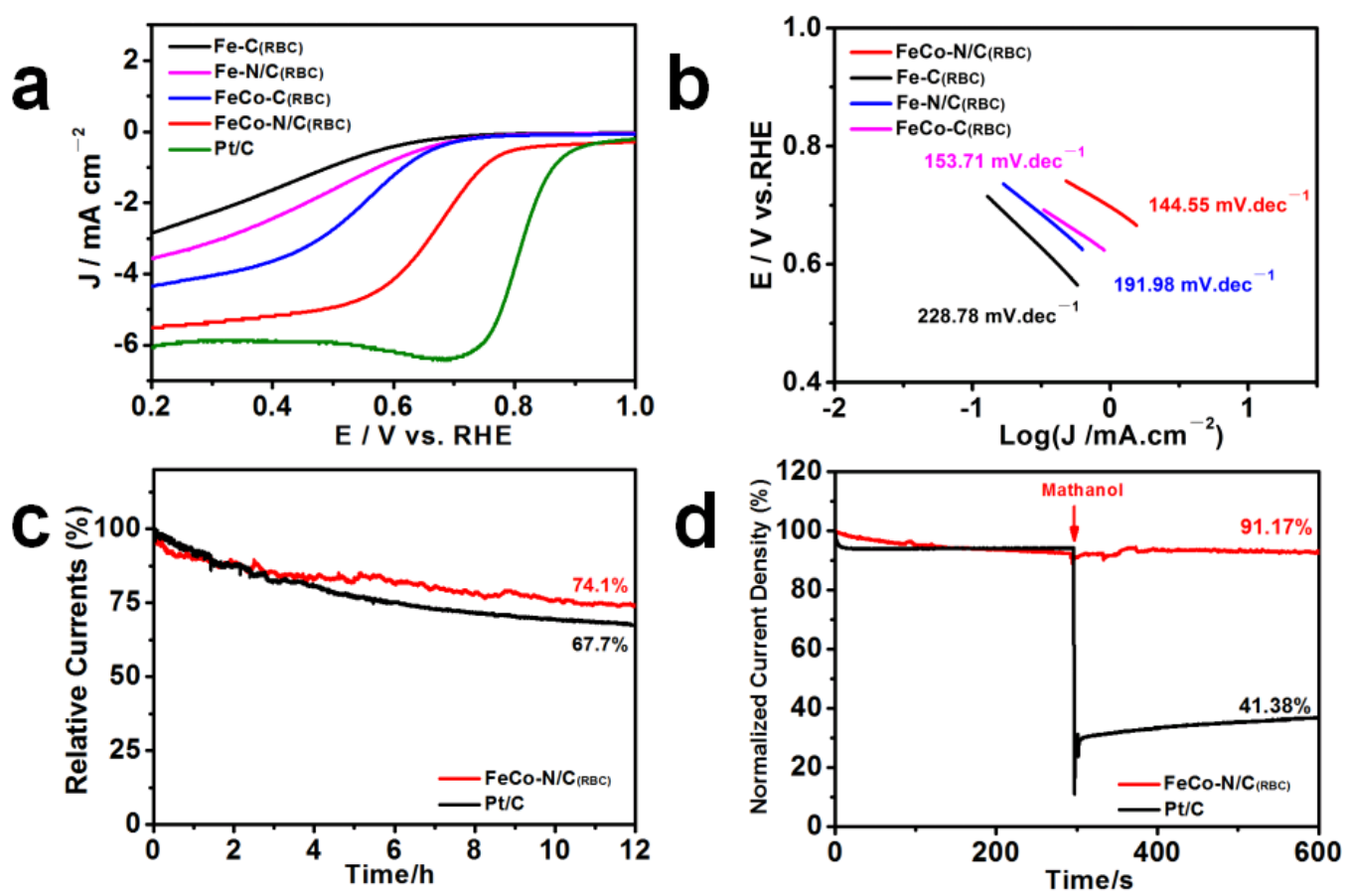

Figure 6. (a) LSV curves for ORR at $1600 \mathrm{rpm}$ with a scanning rate of $5 \mathrm{mV} \cdot \mathrm{s}^{-1}$ in $\mathrm{O}_{2}$ saturated $0.1 \mathrm{M}$ $\mathrm{HClO}_{4}$ solution. (b) Tafel plots for ORR in $0.1 \mathrm{M} \mathrm{HClO}_{4}$ solution. (c) $\mathrm{i}-\mathrm{t}$ chronoamperometric responses of $\mathrm{FeCo}-\mathrm{N} / \mathrm{C}_{(\mathrm{RBC})}$ and $20 \mathrm{wt} \%$ commercial $\mathrm{Pt} / \mathrm{C}$ at $0.78 \mathrm{~V}$ in $\mathrm{O}_{2}$-saturated $0.1 \mathrm{M} \mathrm{HClO}_{4}$. (d) $\mathrm{i}-\mathrm{t}$ chronoamperometric responses of $\mathrm{FeCo}-\mathrm{N} / \mathrm{C}_{(\mathrm{RBC})}$ and $20 \mathrm{wt} \%$ commercial $\mathrm{Pt} / \mathrm{C}$ electrodes upon the addition of $3 \mathrm{M}$ methanol in $0.1 \mathrm{M} \mathrm{HClO}_{4}$.

\section{Experimental Section}

\subsection{Materials}

Cobaltous acetate $\left(\mathrm{Co}\left(\mathrm{CH}_{3} \mathrm{CO}_{2}\right)_{2} \cdot 4 \mathrm{H}_{2} \mathrm{O}\right)$, Melamine $\left(\mathrm{C}_{3} \mathrm{H}_{6} \mathrm{~N}_{6}\right)$ and sodium chloride $(\mathrm{NaCl})$ were manufactured by Aladdin Chemical Co., Ltd. (Shanghai, China). Anhydrous ethanol was purchased from Tianjin Deen Chemical Reagent Co., Ltd. (Tianjin, China). Potassium hydroxide $(\mathrm{KOH})$ was purchased from Tianjin Tianli Chemical Reagent Co., Ltd. (Tianjin, China). Nafion (5 wt \%) was obtained from DuPont Corporation. Commercial $20 \mathrm{wt} \% \mathrm{Pt} / \mathrm{C}$ catalysts were purchased from Shanghai Hesen Electric Co., Ltd. (Shanghai, China). Ultrapure water was used in all the experiments. All chemicals used in this study were analytical grade and not further purification.

\subsection{Preparation of Red Blood Cell (RBCs)}

The pig blood was purchased from Guangzhou Hongyang Biotechnology Co., Ltd. (Guangzhou, China), and stored in the fridge at $4{ }^{\circ} \mathrm{C}$. RBCs were isolated from the whole blood, centrifuged at $2000 \mathrm{rpm}$ for $5 \mathrm{~min}$, and washed with normal saline $0.9 \% \mathrm{NaCl}$ solution three times. Then the purified red blood cells were placed in $4 \%$ formaldehyde phosphate buffer solution, fixed at room temperature for $4 \mathrm{~h}$, and rinsed with ultrapure water three times. Next, the fixed RBCs were dried at $60^{\circ} \mathrm{C}$ for $24 \mathrm{~h}$. 


\subsection{Preparation of Catalysts}

The doped catalyst preparation process was as follows. First, $25 \mathrm{mg}$ melamine and $12.5 \mathrm{mg}$ of cobaltous acetate were added into $80 \mathrm{~mL}$ ultrapure water and continually stirred at $70{ }^{\circ} \mathrm{C}$ for $5 \mathrm{~h}$ to obtain the solution. Then, $20 \mathrm{mg}$ of dried RBCs was added into this solution and stirred for $12 \mathrm{~h}$ until a homogeneous mixture was formed. Next, the resulting mixture was filtered and dried at $80{ }^{\circ} \mathrm{C}$ overnight. Finally, the dried mixture was heat-treated at $900{ }^{\circ} \mathrm{C}$ for $1 \mathrm{~h}$ in a nitrogen atmosphere. The obtained black powders were denoted as FeCo-N/C $\mathrm{C}_{(\mathrm{RBC})}$. As a control, Fe- $\mathrm{C}_{(\mathrm{RBC})}, \mathrm{Fe}-\mathrm{N} / \mathrm{C}_{(\mathrm{RBC})}$, or FeCo- $\mathrm{C}_{(\mathrm{RBC})}$ represented the catalysts that were synthesized with $\mathrm{RBC}$, or melamine and $\mathrm{RBC}$, or cobalt acetate and $\mathrm{RBC}$ as raw materials, respectively. The synthesis procedure was the same as $\mathrm{FeCo}-\mathrm{N} / \mathrm{C}_{(\mathrm{RBC})}$.

\subsection{Physical Characterization}

The morphology and size of the prepared catalysts were observed by field emission scanning electron microscopy (FESEM, Hitachi, SU8010, Tokyo, Japan) operated at $15 \mathrm{kV}$ and transmission electron microscopy (TEM, Hitachi JEM-2100) at an acceleration voltage of $200 \mathrm{kV}$. After the catalyst was digested with mixed acid, the content of the element in the samples was determined by an inductively coupled plasma-mass spectrometer (ICP-MS, ELAN DRC-e, Perkin-Elmer Sciex, Norwalk, CT, USA). The phases and composition of the catalysts were analyzed by X-ray diffraction (XRD, Bruker D8 ADVANCE, Berlin German) with graphite monochromatized $\mathrm{Cu} K \alpha(\lambda=0.15406 \mathrm{~nm})$. Raman spectra were recorded using a LabRAM HR Evolution (Horiba, Palaiseau, France) with a $532 \mathrm{~nm}$ Ar-ion laser. The chemical structure was characterized by an X-ray photoelectron spectroscopy spectrometer (XPS, Thermo Scientific Escalab 220i-XL, Thermo Scientific, Waltham, MA, USA). The pore structure and specific surface area were analyzed by $\mathrm{N}_{2}$ adsorption-desorption measurements.

\subsection{Electrochemical Measurements}

The electrochemical measurements were carried out using a $\mathrm{CHI} 760 \mathrm{E}$ electrochemical workstation using a standard three-electrode system in $0.1 \mathrm{M} \mathrm{KOH}$ or $\mathrm{HClO}_{4}$ solution at room temperature. The electrocatalytic performance of the oxygen reduction reaction was measured with a rotating disk electrode (RDE). The catalyst-coated glassy carbon electrode (GC, diameter $5 \mathrm{~mm}$ ) was used as the working electrode, the saturated calomel electrode (SCE) and graphite rod were used as the reference electrode and the counter electrode, respectively. In this paper, all potentials of the SCE reference electrode were calibrated versus a reversible hydrogen electrode (RHE). Before every measurement, the GC electrode was polished with an $\mathrm{Al}_{2} \mathrm{O}_{3}$ slurry $(50 \mathrm{~nm})$ to a mirror, then cleaned with ultrapure water and dried under an infrared lamp. Then, $2 \mathrm{mg}$ of catalyst and $0.5 \mathrm{mg}$ of carbon black (Vulcan XC-72, Cabot, Shanghai, China) were suspended in $500 \mu \mathrm{L}$ of isopropanol/nafion solution ( $485 \mu \mathrm{L}$, isopropanol and $15 \mu \mathrm{L} 5 \mathrm{wt} \%$ Nafion), followed by ultrasonication for $30 \mathrm{~min}$ to form a homogeneous ink. Then, $25 \mu \mathrm{L}$ of the catalyst ink was dropped onto the upper surface of the GC electrode with a micropipette. The loading amount of catalyst was approximately $0.5 \mathrm{mg} \mathrm{cm}^{-2}$.

\section{Conclusions}

In summary, RBCs-derived dual metal ( $\mathrm{Fe}, \mathrm{Co})$-nitrogen-doped carbon $\left(\mathrm{FeCo}-\mathrm{N} / \mathrm{C}_{(\mathrm{RBC})}\right)$ with a $3 \mathrm{D}$ porous network and high surface area was successfully synthesized by pyrolysis of the mixture of RBCs, cobalt acetate and melamine. The porous FeCo-N $/ \mathrm{C}_{(\mathrm{RBC})}$ displays a comparable ORR activity to the commercial $\mathrm{Pt} / \mathrm{C}$ catalyst, with a half-wave potential of $0.821 \mathrm{~V}_{\text {vsRHE }}$ in alkaline media and $0.672 \mathrm{~V}_{\text {vsRHE }}$ in acid electrolyte. Moreover, FeCo$\mathrm{N} / \mathrm{C}_{(\mathrm{RBC})}$ also exhibits excellent methanol tolerance and stability in both acidic and alkaline media, which is superior to the commercial $\mathrm{Pt} / \mathrm{C}$ catalyst. The porous structure enables $\mathrm{FeCo}-\mathrm{N} / \mathrm{C}_{(\mathrm{RBC})}$ catalyst to have a higher surface area and more active site exposure, result- 
ing in excellent ORR activity. This work provides a novel way for exploiting green, natural and sustainable resources to prepare high performance, durable composite catalysts.

Supplementary Materials: The following supporting information can be downloaded at: https:/ www.

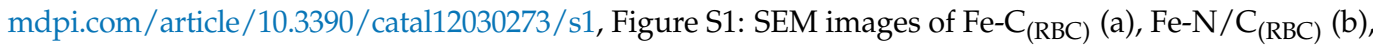
FeCo- $\mathrm{C}_{(\mathrm{RBC})}(\mathrm{c})$; Figure $\mathrm{S} 2$ : $\mathrm{N}_{2}$ adsorption-desorption isotherms of $\mathrm{Fe}-\mathrm{C}_{(\mathrm{RBC})}, \mathrm{Fe}-\mathrm{N} / \mathrm{C}_{(\mathrm{RBC})}$ and FeCo$\mathrm{C}_{(\mathrm{RBC})}(\mathrm{a}-\mathrm{C})$, pore-size distributions of $\mathrm{Fe}-\mathrm{C}_{(\mathrm{RBC})}, \mathrm{Fe}-\mathrm{N} / \mathrm{C}_{(\mathrm{RBC})}$ and $\mathrm{FeCo}-\mathrm{C}_{(\mathrm{RBC})}(\mathrm{d}-\mathrm{f})$; Figure S3: High-resolution N1s XPS spectrum of $\mathrm{Fe}-\mathrm{C}_{(\mathrm{RBC})}, \mathrm{Fe}-\mathrm{N} / \mathrm{C}_{(\mathrm{RBC})}$ and $\mathrm{FeCo}-\mathrm{C}_{(\mathrm{RBC})}$; Figure S4. The histogram for onset potential and half wave potential of $\mathrm{Fe}-\mathrm{C}_{(\mathrm{RBC})}, \mathrm{Fe}-\mathrm{N} / \mathrm{C}_{(\mathrm{RBC})}, \mathrm{FeCo}-\mathrm{C}_{(\mathrm{RBC})}$ and FeCo-N/C $\mathrm{C}_{(\mathrm{RBC})}$ in $0.1 \mathrm{M} \mathrm{KOH}$ solution; Figure S5: Cyclic voltammograms in the region without faradaic processes with different scan rates of $\mathrm{Fe}-\mathrm{C}\left({ }_{(\mathrm{RBC})}(\mathrm{a}), \mathrm{Fe}-\mathrm{N} / \mathrm{C}_{(\mathrm{RBC})}(\mathrm{b}), \mathrm{FeCo}-\mathrm{C}_{(\mathrm{RBC})}(\mathrm{c})\right.$ and FeCo-N/C $(\mathrm{RBC})(\mathrm{d})$; Figure S6: LSV curves of FeCo-N/C $(\mathrm{RBC})$ at different rotation rate in $\mathrm{O}_{2}$ saturated $0.1 \mathrm{M} \mathrm{KOH}$ solution (a) and $0.1 \mathrm{M} \mathrm{HClO}_{4}$ solution (b); Figure S7: The histogram for onset potential and half wave potential of $\mathrm{Fe}-\mathrm{C}_{(\mathrm{RBC})}, \mathrm{Fe}-\mathrm{N} / \mathrm{C}_{(\mathrm{RBC})}, \mathrm{FeCo}_{(\mathrm{RBC})}$ and $\mathrm{FeCo}-\mathrm{N} / \mathrm{C}_{(\mathrm{RBC})}$ in $0.1 \mathrm{M} \mathrm{HClO}_{4}$ solution; Table S1: Atomic content of C 1s, Fe 2p, N 1s, O 1s and Co 2p in Fe- $\mathrm{C}_{(\mathrm{RBC})}, \mathrm{Fe}-\mathrm{N} / \mathrm{C}_{(\mathrm{RBC})}$, FeCo-C $(\mathrm{RBC})$ and FeCo-N/C $(\mathrm{RBC})$ from XPS data; Table S2: The ORR activity data in $0.1 \mathrm{M} \mathrm{KOH}$ solution for $\mathrm{FeCo}-\mathrm{N} / \mathrm{C}_{(\mathrm{RBC})}$ and other catalysts from previous reports.

Author Contributions: Z.Z.: methodology, writing-original draft. X.R.: data curation, formal analysis, supervision. X.Y.: investigation, visualization. Z.B.: writing-review \& editing, funding acquisition. L.Y.: conceptualization, writing-review \& editing, funding acquisition. All authors have read and agreed to the published version of the manuscript.

Funding: This research was funded by the National Natural Science Foundation of China, grant number 51872075, 51922008, 52072114 and the 111 project, China, grant number: D17007. This research was also funded by Henan Center for Outstanding Overseas Scientists, China, grant number: GZS2018003.

Data Availability Statement: Not applicable.

Conflicts of Interest: The authors declare no conflict of interest.

\section{References}

1. Yan, D.; Chen, R.; Xiao, Z.; Wang, S. Engineering the electronic structure of $\mathrm{Co}_{3} \mathrm{O}_{4}$ by carbon-doping for efficient overall water splitting. Electrochim. Acta 2019, 303, 316-322. [CrossRef]

2. Montoya, J.H.; Seitz, L.C.; Chakthranont, P.; Vojvodic, A.; Jaramillo, T.F.; Nørskov, J.K. Materials for solar fuels and chemicals. Nat. Mater. 2017, 16, 70-81. [CrossRef]

3. Fu, Y.; Yu, H.-Y.; Jiang, C.; Zhang, T.-H.; Zhan, R.; Li, X.; Li, J.-F.; Tian, J.-H.; Yang, R. NiCo Alloy Nanoparticles Decorated on N-Doped Carbon Nanofibers as Highly Active and Durable Oxygen Electrocatalyst. Adv. Funct. Mater. 2017, $28,1705094$. [CrossRef]

4. Wang, Y.; Zou, Y.; Tao, L.; Wang, Y.; Huang, G.; Du, S.; Wang, S. Rational design of three-phase interfaces for electrocatalysis. Nano Res. 2019, 12, 2055-2066. [CrossRef]

5. Badam, R.; Hara, M.; Huang, H.-H.; Yoshimura, M. Synthesis and electrochemical analysis of novel $\mathrm{IrO}_{2}$ nanoparticle catalysts supported on carbon nanotube for oxygen evolution reaction. Int. J. Hydrogen Energy 2018, 43, 18095-18104. [CrossRef]

6. Huang, G.; Xiao, Z.; Chen, R.; Wang, S. Defect Engineering of Cobalt-Based Materials for Electrocatalytic Water Splitting. ACS Sustain. Chem. Eng. 2018, 6, 15954-15969. [CrossRef]

7. Seh, Z.W.; Kibsgaard, J.; Dickens, C.F.; Chorkendorff, I.; Nørskov, J.K.; Jaramillo, T.F. Combining theory and experiment in electrocatalysis: Insights into materials design. Science 2017, 355, eaad4998. [CrossRef]

8. Zeng, Y.; Chen, L.; Chen, R.; Wang, Y.; Xie, C.; Tao, L.; Huang, L.; Wang, S. One-step, room temperature generation of porous and amorphous cobalt hydroxysulfides from layered double hydroxides for superior oxygen evolution reactions. J. Mater. Chem. A 2018, 6, 24311-24316. [CrossRef]

9. Kumar, A.; Ciucci, F.; Morozovska, A.N.; Kalinin, S.V.; Jesse, S. Measuring oxygen reduction/evolution reactions on the na-noscale. Nat. Chem. 2011, 3, 707-713. [CrossRef]

10. Garapati, M.S.; Sundara, R. Highly efficient and ORR active platinum-scandium alloy-partially exfoliated carbon nanotubes electrocatalyst for Proton Exchange Membrane Fuel Cell. Int. J. Hydrogen Energy 2019, 44, 10951-10963. [CrossRef]

11. You, C.; Zen, X.; Qiao, X.; Liu, F.; Shu, T.; Du, L.; Zeng, J.; Liao, S. Fog-like fluffy structured N-doped carbon with a superior oxygen reduction reaction performance to a commercial $\mathrm{Pt} / \mathrm{C}$ catalyst. Nanoscale 2015, 7, 3780-3785. [CrossRef]

12. Wang, Q.; Lei, Y.; Chen, Z.; Wu, N.; Wang, Y.; Wang, B.; Wang, Y. Fe/Fe 3 C@C nanoparticles encapsulated in N-doped grapheneCNTs framework as an efficient bifunctional oxygen electrocatalyst for robust rechargeable Zn-air batteries. J. Mater. Chem. A 2018, 6, 516-526. [CrossRef] 
13. Zhao, H.; Xing, T.; Li, L.; Geng, X.; Guo, K.; Sun, C.; Zhou, W.; Yang, H.; Song, R.; An, B. Synthesis of cobalt and nitrogen co-doped carbon nanotubes and its ORR activity as the catalyst used in hydrogen fuel cells. Int. J. Hydrogen Energy 2019, 44, 25180-25187. [CrossRef]

14. Feng, Y.; Alonso-Vante, N. Nonprecious metal catalysts for the molecular oxygen-reduction reaction. Phys. Status Solidi B 2008, 245, 1792-1806. [CrossRef]

15. Nie, Y.; Li, L.; Wei, Z. Recent advancements in Pt and Pt-free catalysts for oxygen reduction reaction. Chem. Soc. Rev. 2015, 44, 2168-2201. [CrossRef]

16. You, C.; Liao, S.; Li, H.; Hou, S.; Peng, H.; Zeng, X.; Liu, F.; Zheng, R.; Fu, Z.; Li, Y. Uniform nitrogen and sulfur co-doped carbon nanospheres as catalysts for the oxygen reduction reaction. Carbon 2014, 69, 294-301. [CrossRef]

17. Chen, Q.; Tan, X.; Liu, Y.; Liu, S.; Li, M.; Gu, Y.; Zhang, P.; Ye, S.; Yang, Z.; Yang, Y. Biomass-derived porous graphitic carbon materials for energy and environmental applications. J. Mater. Chem. A 2020, 8, 5773-5811. [CrossRef]

18. Wang, M.; Ma, J.; Yang, H.; Lu, G.; Yang, S.; Chang, Z. Nitrogen and Cobalt Co-Coped Carbon Materials Derived from Biomass Chitin as High-Performance Electrocatalyst for Aluminum-Air Batteries. Catalysts 2019, 9, 954. [CrossRef]

19. Babu, K.F.; Rajagopalan, B.; Chung, J.S.; Choi, W.M. Facile synthesis of graphene/N-doped carbon nanowire composites as an effective electrocatalyst for the oxygen reduction reaction. Int. J. Hydrogen Energy 2015, 40, 6827-6834. [CrossRef]

20. You, C.; Liao, S.; Qiao, X.; Zeng, X.; Liu, F.; Zheng, R.; Song, H.; Zeng, J.; Li, Y. Conversion of polystyrene foam to a highperformance doped carbon catalyst with ultrahigh surface area and hierarchical porous structures for oxygen reduction. J. Mater. Chem. A 2014, 2, 12240-12246. [CrossRef]

21. Qiao, X.; You, C.; Shu, T.; Fu, Z.; Zheng, R.; Zeng, X.; Li, X.; Liao, S. A one-pot method to synthesize high performance multielement co-doped reduced graphene oxide catalysts for oxygen reduction. Electrochem. Commun. 2014, 47, 49-53. [CrossRef]

22. Peng, H.; Hou, S.; Dang, D.; Zhang, B.; Liu, F.; Zheng, R.; Luo, F.; Song, H.; Huang, P.; Liao, S. Ultra-high-performance doped carbon catalyst derived from o-phenylenediamine and the probable roles of Fe and melamine. Appl. Catal. B Environ. 2014, 158-159, 60-69. [CrossRef]

23. Liu, J.; Fan, C.; Liu, G.; Jiang, L. MOF-derived dual metal (Fe, Ni)—Nitrogen-doped carbon for synergistically enhanced oxygen reduction reaction. Appl. Surf. Sci. 2021, 538, 148017. [CrossRef]

24. Huang, H.; Wang, Q.; Wei, Q.; Huang, Y. Nitrogen doped mesoporous carbon derived from copolymer and supporting cobalt oxide for oxygen reduction reaction in alkaline media. Int. J. Hydrogen Energy 2015, 40, 6072-6084. [CrossRef]

25. Wong, W.; Daud, W.; Mohamad, A.; Loh, K. Effect of temperature on the oxygen reduction reaction kinetic at nitrogen-doped carbon nanotubes for fuel cell cathode. Int. J. Hydrogen Energy 2015, 40, 11444-11450. [CrossRef]

26. Peng, H.; Mo, Z.; Liao, S.; Liang, H.; Yang, L.; Luo, F.; Song, H.; Zhong, Y.; Zhang, B. High Performance Fe- and N- Doped Carbon Catalyst with Graphene Structure for Oxygen Reduction. Sci. Rep. 2013, 3, 1765-1767. [CrossRef]

27. He, X.; Yin, F.; Li, G. A Co/metal-organic-framework bifunctional electrocatalyst: The effect of the surface cobalt oxidation state on oxygen evolution/reduction reactions in an alkaline electrolyte. Int. J. Hydrogen Energy 2015, 40, 9713-9722. [CrossRef]

28. Wang, G.; Li, J.; Liu, M.; Du, L.; Liao, S. Three-Dimensional Biocarbon Framework Coupled with Uniformly Distributed FeSe Nanoparticles Derived from Pollen as Bifunctional Electrocatalysts for Oxygen Electrode Reactions. ACS Appl. Mater. Interfaces 2018, 10, 32133-32141. [CrossRef]

29. Sevilla, M.; Sanchís, C.; Valdés-Solís, T.; Morallón, E.; Fuertes, A.B. Synthesis of Graphitic Carbon Nanostructures from Sawdust and Their Application as Electrocatalyst Supports. J. Phys. Chem. C 2007, 111, 9749-9756. [CrossRef]

30. Wang, H.; Chang, F.; Gu, J.; Xie, X.; Chen, H.; Bai, Z.; Yang, L.; Yang, X. Highly efficient catalytic CoS1.097 embedded in biomass nanosheets for oxygen evolution reaction. Int. J. Hydrogen Energy 2020, 45, 2765-2773. [CrossRef]

31. Wang, G.; Peng, H.; Qiao, X.; Du, L.; Li, X.; Shu, T.; Liao, S. Biomass-derived porous heteroatom-doped carbon spheres as a high-performance catalyst for the oxygen reduction reaction. Int. J. Hydrogen Energy 2016, 41, 14101-14110. [CrossRef]

32. Wang, G.; Deng, Y.; Yu, J.; Zheng, L.; Du, L.; Song, H.; Liao, S. From Chlorella to Nestlike Framework Constructed with Doped Carbon Nanotubes: A Biomass-Derived, High-Performance, Bifunctional Oxygen Reduction/Evolution Catalyst. ACS Appl. Mater. Interfaces 2017, 9, 32168-32178. [CrossRef]

33. Liu, F.; Peng, H.; You, C.; Fu, Z.; Huang, P.; Song, H.; Liao, S. High-Performance Doped Carbon Catalyst Derived from Nori Biomass with Melamine Promoter. Electrochim. Acta 2014, 138, 353-359. [CrossRef]

34. Wang, H.; Li, W.; Zhu, Z.; Wang, Y.; Li, P.; Luo, H.; Xiao, Z.; Wang, J.; Tian, Q.; Xue, Y.; et al. Fabrication of an N-doped mesoporous bio-carbon electrocatalyst efficient in Zn-air batteries by an in situ gas-foaming strategy. Chem. Commun. 2019, 55, 15117-15120. [CrossRef]

35. Guo, C.-Z.; Chen, C.-G.; Luo, Z.-L. A novel nitrogen-containing electrocatalyst for oxygen reduction reaction from blood protein pyrolysis. J. Power Sources 2014, 245, 841-845. [CrossRef]

36. Maruyama, J.; Hasegawa, T.; Amano, T.; Muramatsu, Y.; Gullikson, E.M.; Orikasa, Y.; Uchimoto, Y. Pore Development in Carbonized Hemoglobin by Concurrently Generated MgO Template for Activity Enhancement as Fuel Cell Cathode Catalyst. ACS Appl. Mater. Interfaces 2011, 3, 4837-4843. [CrossRef]

37. Jiang, W.-J.; Hu, W.-L.; Zhang, Q.-H.; Zhao, T.-T.; Luo, H.; Zhang, X.; Gu, L.; Hu, J.-S.; Wan, L.-J. From biological enzyme to single atomic Fe-N-C electrocatalyst for efficient oxygen reduction. Chem. Commun. 2018, 54, 1307-1310. [CrossRef]

38. Zhang, S.; Zhang, H.; Liu, Q.; Chen, S. Fe-N doped carbon nanotube/graphene composite: Facile synthesis and superior electrocatalytic activity. J. Mater. Chem. A 2013, 1, 3302-3308. [CrossRef] 
39. Li, Y.; Li, T.; Yao, M.; Liu, S. Metal-free nitrogen-doped hollow carbon spheres synthesized by thermal treatment of poly(ophenylenediamine) for oxygen reduction reaction in direct methanol fuel cell applications. J. Mater. Chem. 2012, 22, 10911-10917. [CrossRef]

40. Bonaccorso, F.; Colombo, L.; Yu, G.; Stoller, M.; Tozzini, V.; Ferrari, A.C.; Ruoff, R.S.; Pellegrini, V. Graphene, related twodimensional crystals, and hybrid systems for energy conversion and storage. Science 2015, 347, 1246501. [CrossRef]

41. Wanjun, T.; Donghua, C. Mechanism of thermal decomposition of cobalt acetate tetrahydrate. Chem. Pap. 2007, 61, 329-332. [CrossRef]

42. Tang, S.; Zhou, X.; Xu, N.; Bai, Z.; Qiao, J.; Zhang, J. Template-free synthesis of three-dimensional nanoporous N-doped graphene for high performance fuel cell oxygen reduction reaction in alkaline media. Appl. Energy 2016, 175, 405-413. [CrossRef]

43. Jia, J.; Li, X.; Qin, H.; He, Y.; Ni, H.; Chi, H. CoO nanorods/C as a high performance cathode catalyst in direct borohydride fuel cell. J. Alloys Compd. 2020, 820, 153065. [CrossRef]

44. Niu, Y.; Yuan, Y.; Zhang, Q.; Chang, F.; Yang, L.; Chen, Z.; Bai, Z. Morphology-controlled synthesis of metal-organic frame-works derived lattice plane-altered iron oxide for efficient trifunctional electrocatalysts. Nano Energy 2021, 82, 105699. [CrossRef] 